〔86〕Saran の溶融紡系における微細構造の変化

第 1 報 Saran** の溶融紡系ならびに試料の作製

(1958 年 12 月 9 日受理)

角田吉雄*・小林祐二**相島逸穂*

\begin{abstract}
要 旨 Saranの溶融紡系および延伸過程における諸条件のうち, filament の機械的性質に影響を及 ぼす因子をその寄与の大きさの順化並へると，延伸比》命却浴温度＞延伸温度＞紡口温度となる。微細構造の 変化を追究するのに必要な試料 40 個を上記諸因子をそれぞれ变化させて作製した。これら試料のうち, 次の 3 個の model filamenet が含まれている。(1) 等方性非晶質 model filament; 試料の延伸前の状㸃を規定す るもので，窚維としての機械的性能は具備しない。(2) 標準 model filament; filament の延伸ならびに熱 処理挙動を検討する埸合の標準となるもので，工莱的に生産されている Saran filament はこれに相当する。 (3) 異方性結晶質 model filament；極度の熱処理, 超延伸を行なった filament で, 高度に配向した一種の 理想的状热を表わすものである。この filament は非常に fibril 化しやすく,ひっぱり強度は 3 ないし $4 \mathrm{~g} / \mathrm{d}$ に達するが、ひっぱり伸度は拉おむね $10 \%$ 以下である。
\end{abstract}

\section{1. 緒言}

Saran はよく知られているごとく塩化ビニリデン（以 $下 \mathrm{VeCl}_{2}$ と略称) を主体とした塩化ビニル(以下 $\mathrm{VnCl}$ と 略称) との共重合体であって, 本研究で使用した重合体の 組成は, $\mathrm{VeCl}_{2}: \mathrm{VnCl}=88.7: 11.3$ (重量比)のものである (数值分析值熖よる)。分子量は正確に は不明であるが，大体 2 万前後”之考え られ, 軟化点は 150 ないし $155^{\circ} \mathrm{C}$ であっ て, $180^{\circ} \mathrm{C}$ ないし $185^{\circ} \mathrm{C}$ で粘稠な溶融体 となるものである。また重合物は常に安

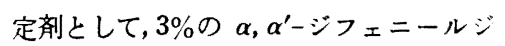
エチルエーテルを可塑郕として， $3 \%$ の ジェチルフタレートを含むものである。 この重合物を長時間にわたって高温に保 つと, 重合体は分解を始的, 塩酸を放出 して気泡を生ずるとともにしだいに黒化 し, 重合物中に polyene 構造を生ずるこ とが知られている2。<smiles>CC(Cl)C(Cl)C(Cl)C(Cl)=CCCC(Cl)(Cl)C(Cl)(Cl)C(Cl)(Cl)C(Cl)C(C)Cl</smiles>

Saranの溶融紡采を研究するには，まず重合物を安定な 溶融状態保持することが最も重要であるが，本実験に 用いた重合物は，加工上全然支障のない安定性を有する ものである。本報告は浴融紡系の概念的な説明を行なう とともに,この重合物を溶融紡禾するに際して, filament

* 旭ダウ株式会社延岡工場(宮崎県延岡市恒富)

** Saran はポリ㙁化ビニリテン采瀻維であり旭ダウ株式会 社の登録商標である。
の微細構造が変化していく過程を調へるために必要な試 料,ならびに model filament のつくり方について述へ たものである。

\section{2. 実 験 法}

2.1 紡 系 法

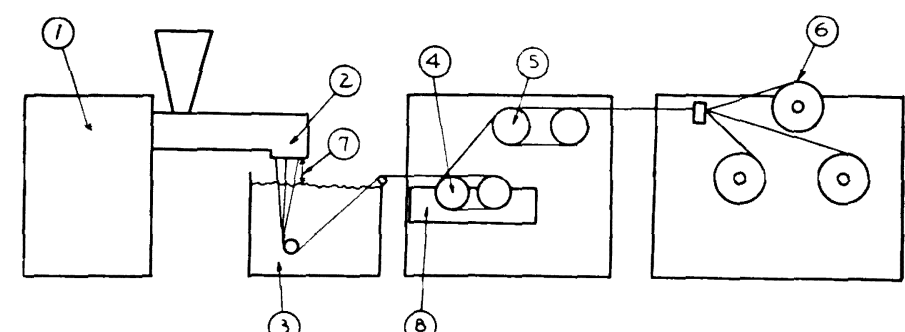
(1) 紡米機
(4) 1 段ローラー
(7) die-bath 間距䧺
(2) 紡口(die)
(3) 冷却浴 (bath)
(5) 2 段ローラー
(8) 延伸加埯浴
(6) 巻取用ボビン

第 1 図 Saranの溶融紡系の概念図

Saranの溶融紡采法に関しては, すでにかなり詳

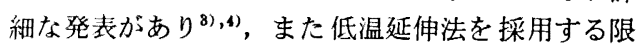
り, 本実験の方法も上記文献の方法と特に異なった 点はない。実験結果の記述を簡略化するために, 紡 釆機の概要および各部の名称を第 1 図に示した。使 用した紡采機は, $Z$ ニッケル製 $3 / 4$ in $\phi$ 電熱式紡采機で あり,スクリューの圧縮比は 5.0 である。紡口の材質も $Z$ ニッケルを用い, これに $0.8 \mathrm{~mm} \phi \times 1 \mathrm{~mm}$ (長さ)の紡 禾孔 3 個を付した。紡系された単纎維は繊度 1000 およ び $300 \mathrm{~d}(\mathrm{~d}:$ デニール)のものであり,繊維の巻取速度は いずれも $120 \mathrm{~m} / \mathrm{min}$ であった。

\section{2 強伸度測定法}


強伸度の測定は塩化ビニリデン采フィラメント糸試験 法5)に準拠して行ない，その結果は試料数十個の平均で 表示した。なお測定は島津製, 容量 $3 \mathrm{~kg}$ 電動式ショッ パー試験機を使用し， $20^{\circ} \mathrm{C}$ の恒温室中で行なった。

\subsection{Stretching tension $の$ 測定}

第 1 図に示す 1 段ローラーと 2 段ローラーとの間で, filament に生ずる Stretching tension (以下 tension と 略称) の测定は, 東洋精機製 tension meter で, 容量 $100,500,1000 \mathrm{~g}$ のものを適宜使用して行なった。測定 の結果の表示は, 測定值の中央値とともに最大最小の差 も併記した。

\section{3. 紡夈条件の検討}

filament の機械的性質を左右する紡禾条件として, 経 験的に知られているものは，(1)溶融温度，(2) die-bath 間距瀖（第 1 図中, 紡口面と泠却浴面との間の距離 (7)), (3) 椧却浴温度, (4) 延伸温度 (第1図中 8) 浴温), (5) 延 伸比，(6)巻取速度などがある。しかしながら,これらの 因子のすべてを組み合わせて, 微細構造に関する知見を 得ることはきわめて困難である。このため主要な因子を 見出す目的で次のような条件で実験を行なった。この実 験では filament の機械的性質と, 延伸中に filament に 生ずる tensionとを測定した。この実験の結果を整理し

第 1 表 実 験 条 件

\begin{tabular}{|c|c|c|}
\hline 因子 名 & 水準 & 件 \\
\hline 紡口温度 & 4 & $170,175,180,185^{\circ} \mathrm{C}$ \\
\hline die-bath 間距離 & 2 & $400,600 \mathrm{~mm}$ \\
\hline 冷却浴温度 & 10 & $\begin{array}{l}5,8,15,25,30,35,40, \\
50,60,70^{\circ} \mathrm{C}\end{array}$ \\
\hline 延伸温度 & 4 & $20,30,40,50^{\circ} \mathrm{C}$ \\
\hline 延伸比 & 8 & $\begin{array}{l}1.0,2.0,2.5,3.0,3.5 \text {, } \\
4.0,4.5,4.8\end{array}$ \\
\hline 巻取速度 & 1 & $120 \mathrm{~m} / \mathrm{min}$ \\
\hline
\end{tabular}

て，上記の諸因子が filament の機械的性質に及ぼす影 響の寄与を大きさの順に並べると, 延伸比>冷却浴温度 >延伸温度>紡口温度〉その他となることがわかった。 filament の tension は, 延伸比とともに大きく変化す る,たとえば延伸温度 $30^{\circ} \mathrm{C} に$ におて得られた結果を tension と延伸比を両軸にとって図示すると第 2 図のご とく，傾斜の異なった 2 つ直線で表わされる。この 2 つの直線の交点 (以下田折点と称す) は延伸比 3.7 , tension 約 $50 \mathrm{~g} / 1000 \mathrm{~d}$ に相当するものである。さらに 延伸温度 $30^{\circ} \mathrm{C}$ で得られた filament ひっぱり強度と,こ の tension を両軸にとって図示すると, 第 3 図の実線の

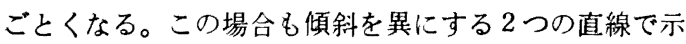
され，延伸比-tension の関倸と同様に $50 \mathrm{~g} / 1000 \mathrm{~d}$ の

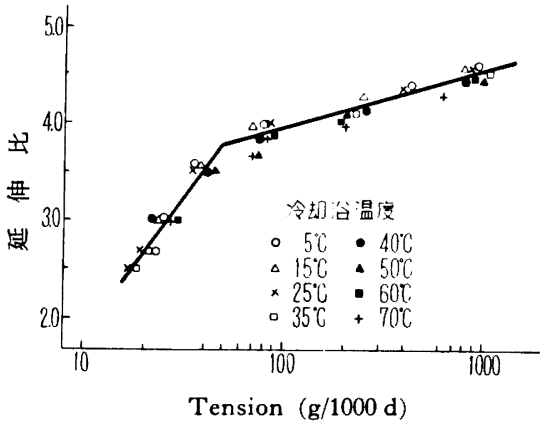

第 2 図延伸比と tension の関係(延伸温度 $30^{\circ} \mathrm{C}$, 冷却浴温度 $0 \sim 70^{\circ} \mathrm{C}$ )

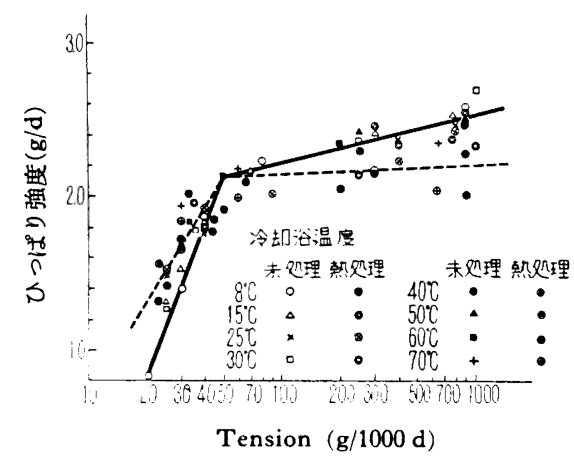

第 3 図ひっぱり強度と Stretching Tension の 関釈, 延伸温度 $30^{\circ} \mathrm{C}$, 冷却浴温度 $0 \sim 70^{\circ} \mathrm{C}$, 延伸比 $2.0 \sim 4.7$

（実線は末処理采のひっぱり強度を示し，点線は 緊張熱処理後のひっぱり強度を示す)

tension で, 届折点を示すのは注目すべきである。また この filament を緊張熱処理 $\left(85^{\circ} \mathrm{C}\right.$, 方法は本報告にあと で述べる)すると,この届折点を境として，ひっぱり強度 は第 3 図における点線に示すように変って行く。すなわ ち届折点以下の tension で得られた filament のひっぱり 強度は熱処理によって增加し, 逆にこの届折点の tension 以上では, 得られた filament のひっぱり強度は低下寸 る。このことは用折点が延伸過程における 1 つの特異点 であることを示している。届折点において熱処理挙動が 逆転するということは次のごとくして確かめられる。す なわち届折点より低い tension の領域で熱処理によって

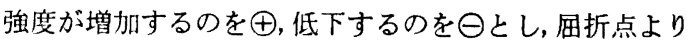
高いtensionの領域でつくられた filament が熱処理で強

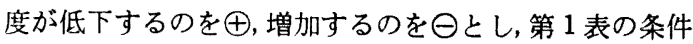
のうち, 紡口温度 $180^{\circ} \mathrm{C}$, 延伸温度 $30^{\circ} \mathrm{C}$, die-bath 間距 離 $600 \mathrm{~mm}$, 巻取速度 $120 \mathrm{~m} / \mathrm{min}$ を一定に保って, 延伸 比, 冷却浴温度を変えた 80 個のデータについて整理する

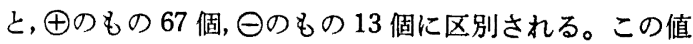


第 2 表 試料の作製条件

（1）冷却浴温度-延伸比-延伸温度を変化させた場合

\begin{tabular}{|c|c|c|c|c|c|c|c|c|}
\hline \multirow{2}{*}{$\frac{\text { 冷却浴温度 }}{\text { 延伸温度 }} \rightarrow$} & \multicolumn{4}{|c|}{$5^{\circ} \mathrm{C}$} & \multicolumn{4}{|c|}{$30^{\circ} \mathrm{C}$} \\
\hline & $10^{\circ} \mathrm{C}$ & $20^{\circ} \mathrm{C}$ & $30^{\circ} \mathrm{C}$ & $50^{\circ} \mathrm{C}$ & $10^{\circ} \mathrm{C}$ & $20^{\circ} \mathrm{C}$ & $30^{\circ} \mathrm{C}$ & $50^{\circ} \mathrm{C}$ \\
\hline A & 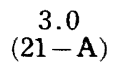 & $\begin{array}{c}3.0 \\
(22-\mathrm{A})\end{array}$ & $\begin{array}{c}3.8 \\
(23-\mathrm{A})\end{array}$ & $\begin{array}{c}4.0 \\
(24-\mathrm{A})\end{array}$ & $\begin{array}{c}2.5 \\
(25-\mathrm{A})\end{array}$ & $\begin{array}{c}3.0 \\
(26-\mathrm{A})\end{array}$ & $\begin{array}{c}3.2 \\
(27-\mathrm{A})\end{array}$ & $\begin{array}{c}4.0 \\
(28-\mathrm{A})\end{array}$ \\
\hline B & $\begin{array}{c}3.4 \\
(21-\mathrm{B})\end{array}$ & $\begin{array}{c}3.5 \\
(22-\mathrm{B})\end{array}$ & $\begin{array}{c}4.1 \\
(23-B)\end{array}$ & $\begin{array}{c}4.8 \\
(24-B)\end{array}$ & $\begin{array}{c}3.0 \\
(25-B)\end{array}$ & $\begin{array}{c}3.25 \\
(26-\mathrm{B})\end{array}$ & $\begin{array}{c}3.5 \\
(27-\mathrm{B})\end{array}$ & $\begin{array}{c}4.3 \\
(28-B)\end{array}$ \\
\hline C & $\begin{array}{c}3.7 \\
(21-C)\end{array}$ & $\begin{array}{c}3.8 \\
(22-\mathrm{C})\end{array}$ & $\begin{array}{c}4.2 \\
(23-C)\end{array}$ & $\begin{array}{c}4.9 \\
(24-C)\end{array}$ & $\begin{array}{c}3.3 \\
(25-C)\end{array}$ & $\begin{array}{c}3.5 \\
(26-C)\end{array}$ & $\begin{array}{c}3.75 \\
(27-C)\end{array}$ & $\begin{array}{c}4.5 \\
(28-C)\end{array}$ \\
\hline D & $\begin{array}{c}4.2 \\
(21-D)\end{array}$ & $\begin{array}{c}4.3 \\
(22-D)\end{array}$ & $\begin{array}{c}4.6 \\
(23-D)\end{array}$ & $\begin{array}{c}5.33 \\
(24-\mathrm{D})\end{array}$ & $\begin{array}{c}3.75 \\
(25-\mathrm{D})\end{array}$ & $\begin{array}{c}4.0 \\
(26-\mathrm{D})\end{array}$ & $\begin{array}{c}4.1 \\
(27-D)\end{array}$ & $\begin{array}{c}5.0 \\
(28-D)\end{array}$ \\
\hline
\end{tabular}

（2）延伸比を変化させた場合

冷却温度 $5^{\circ} \mathrm{C}$, 延伸温度 $20^{\circ} \mathrm{C}$

\begin{tabular}{ccccccccc}
\hline \hline 延伸比 & 1.0 & 2.0 & 2.5 & 3.0 & 3.5 & 4.0 & 4.5 & 4.8 \\
& $(4-\mathrm{A})$ & $(4-\mathrm{B})$ & $(4-\mathrm{C})$ & $(4-\mathrm{D})$ & $(4-\mathrm{E})$ & $(4-\mathrm{F})$ & $(4-\mathrm{G})$ & $(4-\mathrm{H})$ \\
\hline
\end{tabular}

注：1.（）の記号は試料番号を示す。

2. 紡采時の共通条件注次のとおりごある。 紡口温度 $180^{\circ} \mathrm{C}$ die-bath 間距離 $600 \mathrm{~mm}$ 卷取速度 $120 \mathrm{~m} / \mathrm{min}$, 楼度 300 デニール

を 2 項確率紙を用いて検定を行なえば、この両者は明ら かに有意な関係を示し，屈折点を境として熱処理挙動が 逆転するという推定を支持する結果を与える。

\section{4. 試㪴の作慗}

\section{1 延伸試料のつくり方}

以上の実験結果に基いて，延伸過程における微細構造 の変化の追求に用、る試料を作製するために，上記 6 因 子のうち, filament の機械的性質に対して大きな奇与を 示した延伸比, 冾却浴温度, 延伸温度の3 者を検討すへきき 因子としてとり上げた。また紡系時 filament の tension が特異な変化を示すことを考虑に入れて, 延伸温度, 冷 却浴温度のすへてて組合せにおいて, tension がこの特 異点の両側にあるような試料が得られるように，できる だけ広、籁围にわたってこれらの3つの因子を変化せし めた。さらに延伸比の影響は非常に大きいので，これに ついては別に詳細に検討することとした。具体的な試料 の作製条件を第 2 表に示す。

\section{2 熱処理方法}

上記のような条件で紡禾された filament は, 熱処理 によってその機械的性質が変化するので，以下の微細構 造の検討を行なら実験においては，ある場合には熱処理 した filament を試料として用いた。熱処理の基準条件 は次のとおりである。（a）緊張熱処理：室温での初長を $2 \%$ 引き伸ばし，この状態でわくに固定して所定温度で 5 分間保持し,ついで泠水中でこの状態のまま急冷し 2 分後取り出して風乾する。(b) 無緊張熱処理 (自由収縮)： filament をなんら固定することなく, 所定の温度の恒温 槽中に投入し自由に収縮せしめたものであって，加温後 の処置は前と同様である。

\section{Model filament}

溶融体が急泠され，ついで延伸されていく過程を研究 するには，急冷された状態に相当する等方性 filament の 性質,ならびに Saran filament として高度にその微細 構造を発達せしめたものの性質を明確にすることが必要 である。われわれはこのため以下のような手段を通じて 等方性 filament 㧍よび高度に配问掞よび結晶化を行な わせた異方性 filament をつくり，この両者を両極端の model filament として考えて比較することとする。

\section{1 等方性 model filament}

前記 $3 / 4$ in 紡系機を用い, 紡口温度 180 ないし $185^{\circ} \mathrm{C}$ で重合物を押し出し, 紡口直下 $60 \mathrm{~mm}$ で, 固体炭酸-メ タノール浴で $-50^{\circ} \mathrm{C}$ に椧却された $\mathrm{ZnCl}_{2}$ 水溶液 ( $d^{30}$ $=1.63$ ) 中に投入し,$-50^{\circ} \mathrm{C}$ で保存する。この filament は，この温度ではほとんど半永久的に無定形のまま保持 され, ひっぱり強度 0.2 ないし $0.3 \mathrm{~g} / \mathrm{d}$ ，ひっぱり伸度 数百\%であって，完全非晶質等方性とみなされるもの である。さらにこの filament をなんら tension を加え ることなく，室温以上に放置すると，若干の結晶化に必 要な時間を経過した後には, 等方性結晶質へと変化する。 このものはひっぱり强度 0.3 ないし $0.5 \mathrm{~g} / \mathrm{d}$, ひっぱり伸 


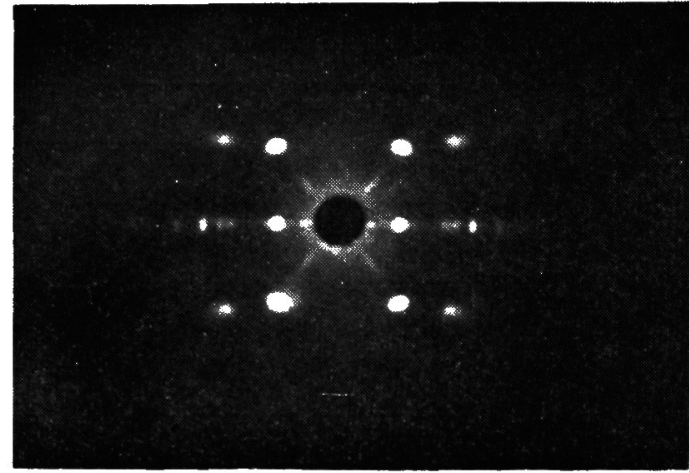

第 4 図超延伸系のX線干涉像

度数\%の堅い糸状態であって，ほとんど完全に等方性で あることは 2 色性, 複屈折あるいはX線による配向の測 定から確かめられた ${ }^{6)}$ 。

\section{2 標準 model filament}

標準紡采条件 (紡口温度 $185^{\circ} \mathrm{C}$, die-bath 間距離 600 $\mathrm{mm}$, 冷却浴温度 $5^{\circ} \mathrm{C}$, 延伸温度 $20^{\circ} \mathrm{C}$, 延伸比 4.0 , 巻取 速度 $120 \mathrm{~m} / \mathrm{min}$, 繊度 $300 \mathrm{~d}$ および $1000 \mathrm{~d}$ )の filament (4-F)を本研究における標隻 model filamentとして選ん だ(第 1 表 (2)参照)。延伸比 4.0 注延伸比-tensionの届折 点よりやや高い延伸比に相当するものである。

\section{3 異方性結晶犋 model filament}

filament の微細構造を高度に発達せしめたものとし て, 超延伸熱処理により model filament をつくった。
H. Harder ${ }^{7)}$ によれば重合物の溶融点より，50 低い温 度までの範囲は, 特殊転移温度領域とも称せられるもの であって, この温度範囲内で適当な延伸速度と延伸温度 を組み合わせることによって，結晶の著しい成長ととも に配向も著しく発達せしめることができる。このように して得られた filamentの物性はひっぱり強度 $3 \sim 4 \mathrm{~g} / \mathrm{d}$, ひっぱり伸度 5〜10\% であって, 強度はかなり增大す るにもかかわらず fibril 化しやすいものである。われわ れはこの方法によって超延伸操作を行ない, Saran の微 細構造の極度に発達した究極的な model filamentとして この超延伸された filament を採用した。第 4 図にその $\mathrm{X}$ 線干涉像を示すように, これは高度の配向性と結晶化 度の向上を表わしていて，ひっぱり強度は $3.4 \sim 3.7 \mathrm{~g} / \mathrm{d}$ に達するが, 結節強度は $0.3 \mathrm{~g} / \mathrm{d}$ 程度の非常にもろいも のであった。この filamentを異方性結晶睤 model あるいは単に超延伸系と呼ぶ。

\section{文献}

1) R.C. Reinhardt : IEC, 35, 422(1943)

2) R.F. Boyer:J. Phys. Chem., 51, 80 (1947)

3) J. Jack and R.A. Horsley: J. Appl. Chem., 4, 178(1954)

4) L.B. Morgan: J. Appl. Chem., 4, $160(1954)$

5) JIS $L-1028(1956)$

6）未発表（本報告続報として，2 色性による配向 $\mathrm{X}$ 線 による配向，複岡折による配向として発表の予定）

7) H. Harder : USP 2,344,511

\title{
The Changes in Fine Structures of Saran Filaments in the Extrusion and Stretching Process
}

\section{The Extrusion of Saran and the Preparation of Samples}

\author{
By Yoshio Tsunoda*, Yuji Kobayashi* and Itsuho Aishima*
}

Among the variables in the extrusion and the stretching process of Saran, the most important factor affecting the mechanical properties of a filament is the stretch ratio. The second, is the temperature of the cooling bath, the third is the stretching temperature and the least important factor is the die temperature. In order to investigate the changes in fine structure of filaments, 40 samples were made under various conditions of the above-mentioned four factors. The following three typical filaments were included in these 40 samples. (1) An isotropic amorphous model filament; this is a typical unoriented filament having no fibrous properties. (2) A standard model filament; this is a commercial Saran filament and is the standard used for comparing the behavior of other samples in stretching and heat treating. (3) An anisotropic crystalline model filament; this is a highly oriented filament prepared under a most severe condition of stretching. It fibrillates easily and its tensile strength is $3 \sim 4 \mathrm{~g} / \mathrm{d}$; however, its tensile elongation is below $10 \%$.

* Nobeoka plant, Asaki-Dow Ltd. (Nobeoka, Miyazaki) 